\title{
CORRECTION
}

\section{Mycobacterium avium complex infection presenting as persistent ascites}

CMAJ has been made aware of an error that occurred in the Apr. 3, 2018, issue. ${ }^{1}$

In the first paragraph on the fourth page, the third sentence read, "Likewise, clarithromycin is a much more potent inhibitor of CYP250 3A4 than azithromycin." This should have read, "Likewise, clarithromycin is a much more potent inhibitor of CYP450 3A4 than azithromycin."

This has been corrected at cmaj.ca.

- Cite as: CMAJ 2018 April 23;190:E515. doi: $10.1503 / \mathrm{cmaj} .180461$

\section{Reference}

1. Auguste BL, Patel AD, Siemieniuk RA. Mycobacterium avium complex infection presenting as persistent ascites. CMAJ 2018;190:E394-7. 